\title{
A simple and robust method for calculating temperatures of granitoid magmas
}

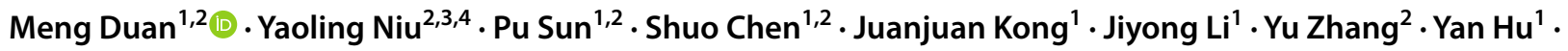 \\ Fengli Shao ${ }^{1}$
}

Received: 26 August 2020 / Accepted: 29 October 2021 / Published online: 22 November 2021

(c) The Author(s) 2021

\begin{abstract}
Calculating the temperatures of magmas from which granitoid rocks solidify is a key task of studying their petrogenesis, but few geothermometers are satisfactory. Zircon saturation thermometry has been the most widely used because it is conceptually simple and practically convenient, and because it is based on experimental calibrations with significant correlation of the calculated zircon saturation temperature $\left(T_{Z r}\right)$ with zirconium $(\mathrm{Zr})$ content in the granitic melt (i.e., $T_{Z r} \propto \mathrm{Zr}_{\mathrm{MELT}}$ ). However, application of this thermometry to natural rocks can be misleading, resulting in the calculated $T_{Z r}$ having no geological significance. This thermometry requires $\mathrm{Zr}$ content and a compound bulk compositional parameter $M$ of the melt as input variables. As the $\mathrm{Zr}$ and $M$ information of the melt is not available, petrologists simply use bulk-rock $\mathrm{Zr}$ content $\left(\mathrm{Zr}_{\mathrm{BULK}-\mathrm{ROCK}}\right)$ and $M$ to calculate $T_{Z r}$. In the experimental calibration, $T_{Z r}$ shows no correlation with $M$, thus the calculated $T_{Z r}$ is only a function of $\mathrm{Zr}_{\text {MELT. }}$. Because granitoid rocks represent cumulates or mixtures of melt with crystals before magma solidification and because significant amount $\mathrm{Zr}$ in the bulk-rock sample reside in zircon crystals of varying origin (liquidus, captured or inherited crystals) with unknown modal abundance, $\mathrm{Zr}_{\text {BULK-ROCK }}$ cannot be equated with $\mathrm{Zr}_{\text {MELT }}$ that is unknown. Hence, the calculated magma temperatures $T_{Z r}$ using $\mathrm{Zr}_{\text {BULK-ROCK }}$ have no significance in both theory and practice. As an alternative, we propose to use the empirical equation $T_{\mathrm{SiO}_{2}}\left({ }^{\circ} \mathrm{C}\right)=-14.16 \times \mathrm{SiO}_{2}+1723$ for granitoid studies, not to rely on exact values for individual samples but focus on the similarities and differences between samples and sample suites for comparison. This simple and robust thermometry is based on experimentally determined phase equilibria with $T \propto 1 / \mathrm{SiO}_{2}$.
\end{abstract}

Keywords Zircon saturation thermometry $\cdot$ Magma temperature $\cdot$ Granitoid magmatism $\cdot \mathrm{SiO}_{2}$ approximation for magma temperature

\section{Introduction}

Editorial handling: Q. Wang

Meng Duan

meng.duan@qdio.ac.cn

$\triangle$ Yaoling Niu

yaoling.niu@durham.ac.uk

1 Key Laboratory of Marine Geology and Environment, Institute of Oceanology, Chinese Academy of Sciences, 7 Nanhai Road, Qingdao, Shandong 266071, China

2 Laboratory for Marine Geology, Qingdao National Laboratory for Marine Science and Technology, 1 Wenhai Road, Qingdao, Shandong 266061, China

3 School of Earth Science and Resources, China University of Geosciences, 29 Xueyuan Road, Beijing 100083, China

4 Department of Earth Sciences, Durham University, Durham DH1 3LE, UK
In studying the petrogenesis of magmatic rocks, determination of magma temperature is one of the basic tasks. This is relatively straightforward for basalts and basaltic rocks because of the experimentally well-established phase relationships between the liquidus phases such as olivine, clinopyroxene and plagioclase and the melt as a function of temperature (e.g., Roeder and Emslie 1970; Bender et al. 1978; Walker et al. 1979; Langmuir and Hanson 1981; Nielsen and Dungan 1983; Weaver and Langmuir 1990; Grove et al. 1992). The magma temperature is essentially linearly proportional to the $\mathrm{MgO}$ content of the melt, which is the $\mathrm{MgO}$ content of quenched basaltic glasses (or approximated with aphyric basalts or groundmass of basalts) (Niu et al. 2002). To calculate the magma temperatures of granites and granitic rocks is not straightforward despite their inverse 
correlation with $\mathrm{SiO}_{2}$ content of the melt (Bowen 1928; Tuttle and Bowen 1958). The difficulty is several fold: (1) with the exception of highly evolved granites and rhyolitic glasses, most granites and granitoid rocks do not represent melts but are cumulates (Niu et al. 2013; Chen et al. 2015, 2016; Lee and Morton 2015; Barnes et al. 2019) or meltsolid mixtures because of incomplete melt-solid separation during melt extraction (containing restite minerals/lithic fragments, Clemens and Stevens 2012) and magma (i.e., crystal mush) evolution owing to high melt viscosity; (2) mineral pairs with temperature-sensitive exchange reactions in granitic rocks, if any (e.g., two-feldspar thermometry, Brown and Parsons 1981; Kroll et al. 1993; Benisek et al. 2004, 2010; Anderson et al. 2008), record temperatures of sub-solidus equilibrium, rather than liquidus temperatures (i.e., melt temperatures of mineral crystallization).

This difficulty has been largely overcome by the zircon saturation thermometry thanks to the meticulous experimental calibration by Watson and co-workers (Watson 1979; Watson and Harrison 1983, 1984; Boehnke et al. 2013). This thermometry has been widely used and is considered to "provide a simple and robust means of estimating magma temperatures" (Miller et al. 2003). We agree that the concept of the zircon saturation thermometry is sound, and the experimental calibration is robust by Watson and coworkers. However, as we show here, application of this thermometry to natural rocks using bulk-rock (instead of melt) compositions is misleading and suggest that caution must be exercised before indiscriminate use of this thermometry.

As an alternative, we propose to use "bulk-rock" $\mathrm{SiO}_{2}$ content as a proxy for estimating granitoid crystallization temperatures, whose individual values should not be considered as "exact", but their comparisons between samples and between sample suites are geologically significant for granitoid petrogenesis.

\section{Zircon saturation thermometry}

Watson and Harrison (1983) show that the saturation behavior of zircon in granitic magmas (during melting and crystallization) depends on both melt composition and temperature, which, on the basis of experimental calibration, is expressed by:

$\operatorname{Ln}\left(D_{Z r}\right)=[-3.80-0.85(M-1)]+12900 / T_{Z r}$

where $D_{Z r}$ is the concentration ratio of $\mathrm{Zr}$ in the stoichiometric zircon to that in the melt $\left(\mathrm{Zr}_{\mathrm{MELT}}\right), T_{Z r}$ is the absolute temperature in Kelvin, and $M$ is the compositional parameter of the equilibrated melt $[M=(\mathrm{Na}+\mathrm{K}+2 \mathrm{Ca}) /(\mathrm{Al} \times \mathrm{Si})]$. This expression has recently been revisited and reaffirmed (Boehnke et al. 2013). Rearranging this equation enables direct calculation of the temperature of the granitic melts (Miller et al. 2003):

$T_{Z r}=12900 /\left[\operatorname{Ln}\left(D_{Z r}\right)+0.85 M+2.95\right]$

Because $\mathrm{Zr}$ in zircon is stoichiometrically constant ( $497,000 \mathrm{ppm}), D_{\mathrm{Zr}}$ is solely a function of $\mathrm{Zr}_{\mathrm{MELT}}$, and $T_{\mathrm{Zr}}$ is thus a function of $\mathrm{Zr}$ content and $M$ value of the melt. This means that if magmas parental to granitic rocks under study are known to be saturated with zircon and if bulk-rock compositions can be approximated as representing the melt, then the magma temperatures can be calculated using Eq. (2), as widely used over the last decades since 1983.

The assumption of zircon saturation is readily proven because of the widespread occurrence of zircon crystals with crystallization ages (at least at the rims and edges of zircon crystals) in all granite and granitoid samples. However, the assumption that the bulk-rock compositions represent melt compositions cannot be true in almost all cases (see above). If granitoids are proven not to represent melt compositions, then Eq. (2) fails simply because neither $D_{\mathrm{Zr}}$ nor $M$ is meaningful. Hence, the zircon saturation thermometry, despite its thermodynamic and experimental footing, cannot be used in practice to calculate the temperatures of magmas parental to granitoid rocks. The problem is serious and is multi-fold.

Although widely used, the bulk-rock $\mathrm{Zr}$ content $\left(\mathrm{Zr}_{\text {BULK-ROCK }}\right)$ is not $\mathrm{Zr}_{\mathrm{MELT}}$, but the sum of $\mathrm{Zr}$ in zircon crystals and $\mathrm{Zr}$ in the rest of the rock. One could assume the latter as representing the melt if the rock is highly evolved, but its $\mathrm{Zr}$ content cannot be determined from the bulk-rock without knowing modal proportions of zircons. In this case, because $\mathrm{Zr}_{\text {BULK-ROCK }}>\mathrm{Zr}_{\text {MELT }}$, the calculated $T_{Z r}$ overestimates the crystallization temperatures of magmas (Miller et al. 2003). On the other hand, for granitoids with dioritic compositions that accumulate/solidify early from the parental magmas of relatively high temperature and low viscosity, $\mathrm{Zr}_{\text {BULK-ROCK }}<\mathrm{Zr}_{\text {MELT }}$ because $\mathrm{Zr}$ still resides largely in the residual/evolving melt at this early stage of crystallization. In this case, the calculated $T_{Z r}$ underestimates the crystallization temperatures of magmas.

In granitoids, inherited and xenocrystic zircons are common, and their contribution to $\mathrm{Zr}_{\mathrm{BULK}-\mathrm{ROCK}}$ is difficult to assess. Hanchar and Watson (2003) put forward a method by using back-scattered electrons (BSE) or cathodoluminescence (CL) images to estimate the volume of inherited zircon, which still has large uncertainty. In this case, the calculated $T_{Z r}$ depends on $\mathrm{Zr}_{\text {BULK-ROCK }}$ that is highly influenced by the volume of inherited and xenocrystic zircons in granitoid samples.

As discussed above, rock samples from granitoid plutons rarely represent pure melt, but cumulates comprising crystals and residual melts. This makes the calculated bulk-rock $M$ parameter irrelevant to the expected $M$ of the melt, which 
can further deviate $T_{Z r}$ from the true melt temperatures. However, as the experimentally calibrated $T_{Z r}$ shows no correlation with $M$ and all other compositional parameters (discussed in more detail below), $M$ is not, but $\mathrm{Zr}_{\text {BULK-ROCK }}$ is, the primary source of the error for the calculated $T_{Z r}$.

The above analysis states explicitly that the zircon saturation thermometry cannot be used to calculate the temperatures of magmas that solidifies to form granitoid plutons using bulk-rock compositions. That is, the calculated $T_{Z r}$ values have large unknown errors and thus have no significance. Figure 1 illustrates these problems. For a melt parental to granitic rocks with $\mathrm{Zr}=400 \mathrm{ppm}$ (moderately enriched $\mathrm{Zr}$ content in the granitoid rocks from natural samples), $M=1.3$ and $T_{Z r} \approx 880^{\circ} \mathrm{C}$, magma cooling causes zircon crystallization and $\mathrm{Zr}$ depletion in the residual melt. When the melt cools to $\sim 790{ }^{\circ} \mathrm{C}$, there will be $\sim 0.05 \mathrm{wt} \%$ zircon crystallized and $\sim 150 \mathrm{ppm} \mathrm{Zr}$ left in the mixture of residual melt and other liquidus phases which are not efficiently segregated from the melt. The $\sim 790{ }^{\circ} \mathrm{C}$ would be mistaken as $T_{\mathrm{Zr}}=880{ }^{\circ} \mathrm{C}$ calculated using Eq. (2) because inefficient zircon separation makes the bulk-rock still have the original $\sim 400 \mathrm{ppm} \mathrm{Zr}$. The calculated $T_{Z r}$ would be even higher if there are inherited/captured zircons in the bulk-rock compositions, which is common in granitoid rocks.

On the other hand, for a melt parental to intermediate cumulate dioritic rocks with $\mathrm{Zr}=400 \mathrm{ppm}$, a higher $M$ of 1.6

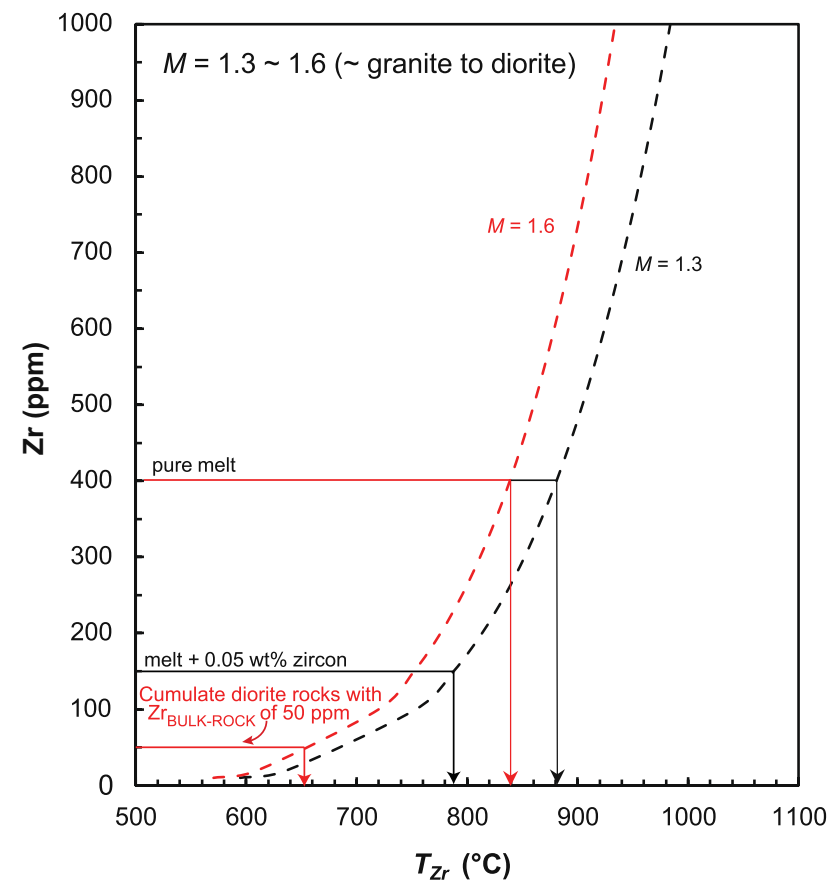

Fig. $1 \mathrm{Zr}$ versus $T_{\mathrm{Zr}}$ plot, visualizing that calculated $T_{\mathrm{Zr}}$ values are a function of $\mathrm{Zr}$ content and $M$ value. $\mathrm{Zr}$ content in the melt phase decreases as the result of cooling and zircon crystallization. Using the bulk-rock $\mathrm{Zr}$ content as the substitute of melt $\mathrm{Zr}$ content would introduce large errors in the estimated magma temperatures and $T_{Z r} \approx 840{ }^{\circ} \mathrm{C}$, early cumulation of dioritic rocks effectively separated from the parental melt with low $\mathrm{Zr}_{\text {BULK-ROCK }}$ content ( $\sim 50 \mathrm{ppm}$ estimated with $0.01 \mathrm{wt} \%$ zircon in the bulk-rock cumulate) would give $T_{Z r}$ of $\sim 650{ }^{\circ} \mathrm{C}$, in huge contrast with the real $T_{Z r}$ of $\sim 840{ }^{\circ} \mathrm{C}$ (Fig. 1). The above simulations may not be perfect but demonstrate significant deviations of the calculated $T_{Z r}$ values using $\mathrm{Zr}_{\text {BULK-ROCK }}$ from the true magma temperature values for different types of granitoid rocks (felsic granitic plutons consisting of crystals and residual melts vs. intermediate dioritic rocks of early cumulate origin with less melt trapped or retained). The examples in Fig. 1 can be further demonstrated by comparing such calculated $T_{Z r}$ values and the $T$ values estimated by using "bulk-rock" $\mathrm{SiO}_{2}$ content of granitoid rocks better reflecting their true crystallization temperatures (see below). Similarly, without knowing major element composition of the melt, but using bulk-rock major element analyses, we can easily have errors on the compound parameter $M$. In addition, uncertainties in the $M$ values between 1.3 and 1.6 due to bulk-rock composition (e.g., containing restite crystals) treated as melt composition would lead to a further $\sim 40 \mathrm{~K}$ deviation in the calculated $T_{Z r}$ values although $M$ shows no understood contribution in the zircon saturation thermometry (see below).

\section{Comparison of data on natural samples with experimental results}

In this section, we use bulk-rock major and trace element data of syn-collisional I-type granitoid samples saturated in zircon from the Qilian, Kunlun and Qinling Orogens in central and western China (Chen et al. 2015, 2016; Zhang et al. 2015; Duan et al. 2016; Li et al. 2016, 2017; Kong

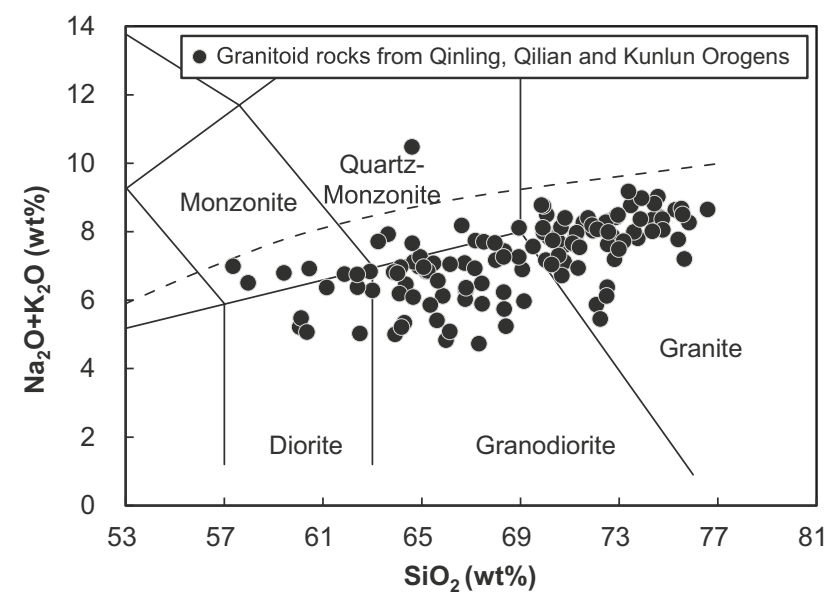

Fig. 2 Total alkalis silica (TAS) diagram showing the compositions of plutonic samples from Qilian, Kunlun and Qinling Orogens (Chen et al. 2015, 2016; Zhang et al. 2015; Duan et al. 2016; Li et al. 2016, 2017; Kong et al. 2017, 2019, 2020; Shao et al. 2017) 


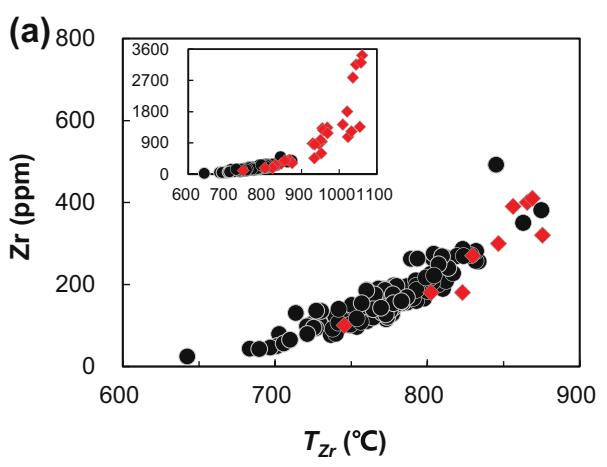

Fig. 3 Plots of the bulk-rock $\mathrm{Zr}$ contents (a) and $D_{\mathrm{Zr} \text {, zircon/melt }}$ (b) against the calculated $T_{\mathrm{Zr}}$ values of granitoids (same samples as in Fig. 2) using the zircon saturation thermometry (Watson and Harrison 1983). For comparison, the experiment data used for zircon thermom-

et al. 2017, 2019, 2020; Shao et al. 2017). In addition, we have collected granitoid data compiled through the EarthChem portal (http://portal.earthchem.org/). This was done to further illustrate that caution is required when using zircon thermometry Eq. (2) to calculate "magma temperatures" for natural granitoid samples.

The syn-collisional granitoids from the Qilian, Kunlun and Qinling Orogens in central and western China show

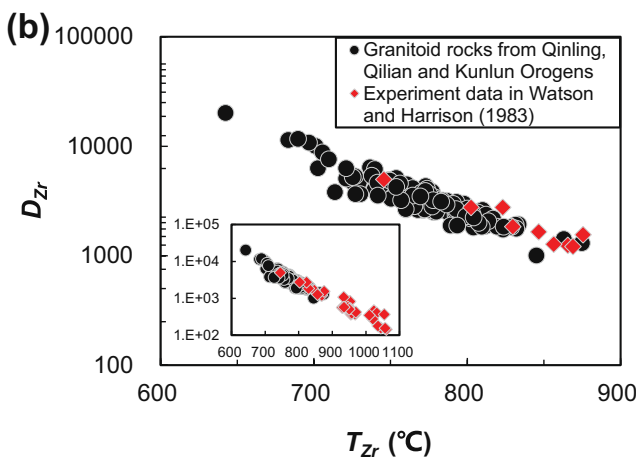

etry calibration (Watson and Harrison 1983) are also plotted. The insets plot all the experimental data. Note that only nine experimental data points are in the compositional range of natural granitoid samples

large compositional variations in the TAS diagram (Fig. 2), reflecting their crystallization from variably evolved magmas with varying temperatures (Chen et al. 2016). Figure 3 shows $\mathrm{Zr}_{\text {BULK-ROCK }}$ and the calculated $D_{Z r}$ plotted against the calculated $T_{Z r}$ Eq. (2) of granitoid samples, compared with the experimental data (Watson and Harrison 1983). The apparent consistency between the two is not proof of the validity of the calculated $T_{Z r}$ for granitoid samples because they are
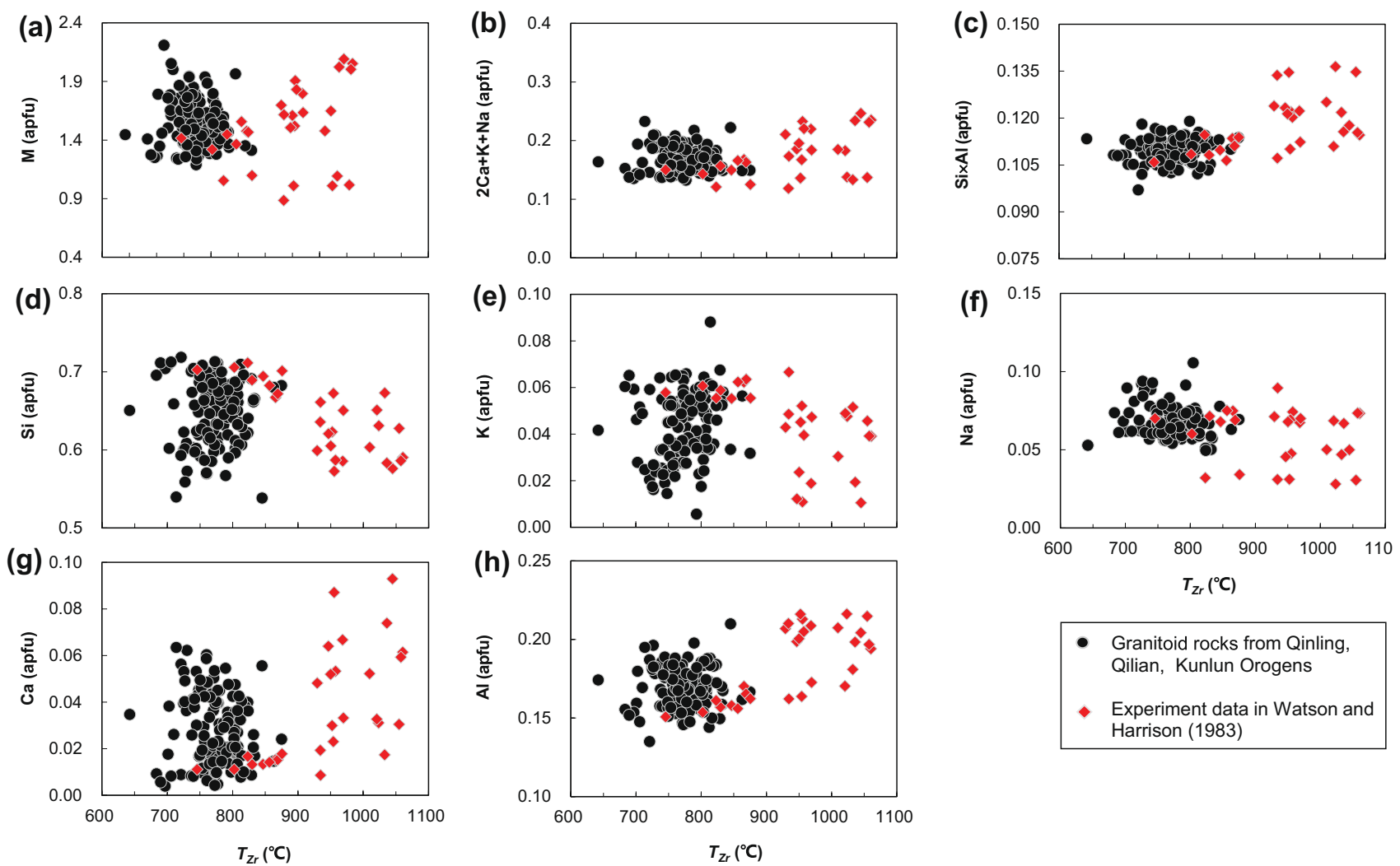

- Granitoid rocks from Qinling Qilian, Kunlun Orogens

- Experiment data in Watson and Harrison (1983)

Fig. 4 Plot of $M[(\mathrm{Na}+\mathrm{K}+2 \mathrm{Ca}) /(\mathrm{Al} \times \mathrm{Si})]$ and independent major element parameters against the calculated $T_{Z r}$ values of granitoids using zircon thermometry (Watson and Harrison 1983) 
intrinsically linked by Eq. (2), but does show the significance of experimental calibration of Eq. (2) with $T_{Z r} \propto \mathrm{Zr}_{\text {BULK-ROCK }}$ and $T_{Z r} \propto 1 / D_{Z r}$. We point out that while there exist many experimental data for the calibration, only nine of these data sets were found to be appropriate for natural samples in terms of melt compositions and temperature range.

To evaluate the compositional effects on magma temperatures or the calculated $T_{Z r}$ using Eq. (2), we plot compositional parameter $M$ Eqs. (1) and (2) and its constituent parameters against the calculated $T_{Z r}$ (Fig. 4) and $\mathrm{Zr}_{\text {BULK-ROCK }}$ (Fig. 5) for both natural rock data and experimental data used for calibrating the equations. One could claim the existence of some sort of correlation between experimental temperatures and experimental charge compositions (although it is not at all obvious), there is certainly no correlation of any sort between the calculated temperatures and compositional parameters for natural bulk-rock compositions. This phenomenon itself is unexpected because $T \propto \mathrm{MgO}$ and $T \propto 1 / \mathrm{SiO}_{2}$ are well understood through experimental petrology (Bowen 1928; Tuttle and Bowen 1958; Gerke and Kilinc 1993; Grove et al. 1997). As seen in Fig. 3 insets and above discussion, most experimental charge temperatures are very high, and the temperature data pertinent to granitoid magmatism are rather sparse (only 9 data points). According to Eq. (1), $M \propto \mathrm{Zr}_{\mathrm{MELT}}$ is expected, which seems to be the case for the experimental data with scatter, but is not true for bulk-rock data $\mathrm{Zr}$ and bulk-rock compositions (i.e., the compound parameter $\mathrm{M}$ and the constituent parameters; Fig. 5). Hence, while the experimental calibration of zircon saturation thermometry is robust, its application to natural granitoid rocks using bulk-rock instead of melt $\mathrm{Zr}$ content is erroneous.
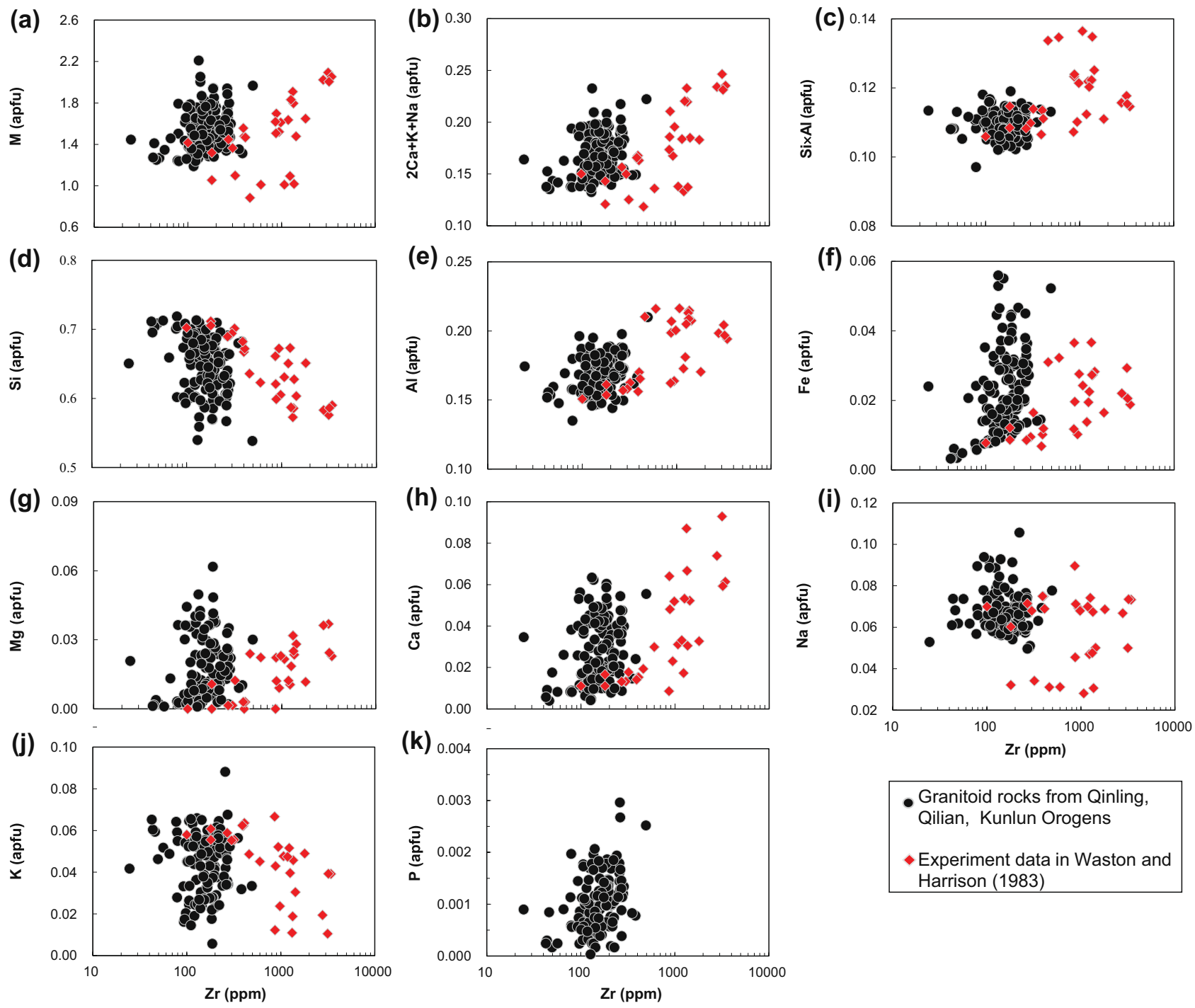

Fig. 5 Co-variations between $M[(\mathrm{Na}+\mathrm{K}+2 \mathrm{Ca}) /(\mathrm{Al} \times \mathrm{Si})]$ and independent major element parameters and bulk-rock $\mathrm{Zr}$ contents of granitoid samples, compared with experimental data 


\section{Comparison of $T_{\mathrm{Zr}}$ and $T_{\mathrm{SiO}_{2}}$ calculated from major element compositions}

$\mathrm{MgO}$ contents of basaltic melts have been demonstrated experimentally to be proportional to the magma temperature (see above and review: $T=1026 \times \mathrm{e}^{[0.01894 \times \mathrm{MgO}(\mathrm{wt} \%)]}$ given by Niu et al. 2002). This simple MgO- $T$ relationship is derived from various experiment data and involves no extra parameters other than $\mathrm{MgO}$ content in basaltic melts (quenched glasses or groundmass; Niu et al. 2002). To explore the relationships between major element abundances (e.g., $\mathrm{SiO}_{2}$ and $\mathrm{MgO}$ ) and temperatures in andesitic and felsic magmas, we compiled the experimental data (including the temperatures and major element compositions of the melts) studying the crystallization evolution of andesitic and felsic magmas (Helz 1976; Carroll and Wyllie 1989; Sisson and Grove 1993; Moore and Carmichael 1998; Alonso-Rerez et al. 2008; Nandedkar et al. 2014, 2016; Ulmer et al. 2018). Only experiments with liquidus minerals of amphibole, plagioclase, quartz and micas which are common mineral phases

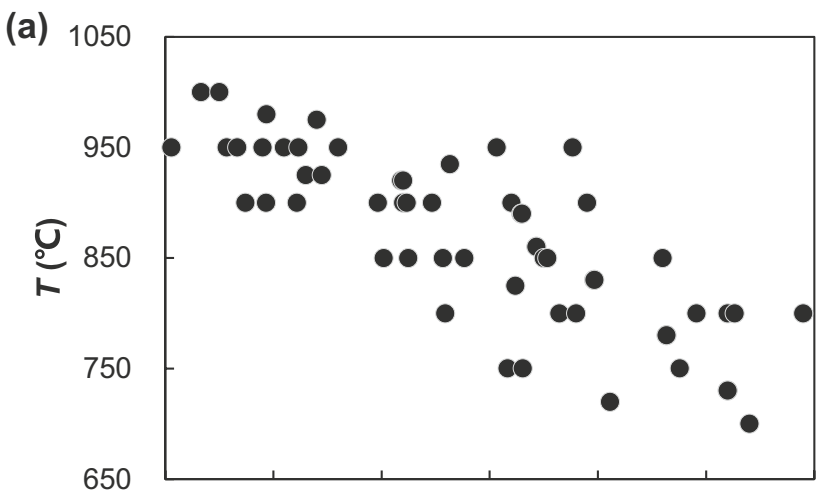

(c)

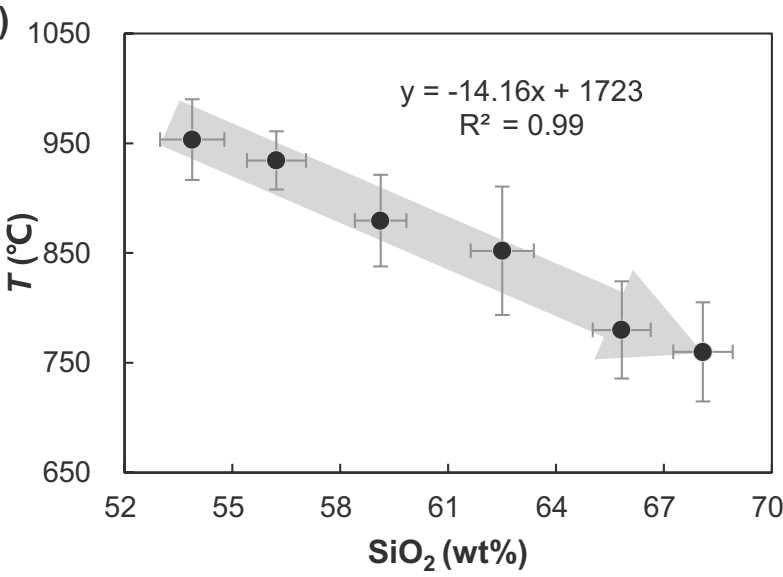

Fig. 6 Plots of silicate melt temperatures measured during experiments against $\mathrm{SiO}_{2}$ and $\mathrm{MgO}$ contents of the compiled experimental data (Helz 1976; Carroll and Wyllie 1989; Sisson and Grove 1993; Moore and Carmichael 1998; Alonso-Rerez et al. 2008; Nandedkar et al. 2014, 2016; Ulmer et al. 2018). The temperatures show a negative correlation with $\mathrm{SiO}_{2}$ (a) and a positive correlation with $\mathrm{MgO}$ in granitoid rocks are used; experimental data with liquidus minerals of olivine, clinopyroxene and orthopyroxene are excluded. The data are shown in Figs. 6a, b.

Figure 6 shows that with decreasing temperature, $\mathrm{SiO}_{2}$ increases and $\mathrm{MgO}$ decreases in the melt, consistent with cooling induced fractional crystallization of the more mafic minerals from the melts (e.g., amphibole). The large scatter in the temperature at a given $\mathrm{SiO}_{2}$ or $\mathrm{MgO}$ results from different experimental conditions (e.g., composition of starting materials, pressure and $\mathrm{H}_{2} \mathrm{O}$ content). Nevertheless, temperature-dependent trends for both $\mathrm{SiO}_{2}$ and $\mathrm{MgO}$ are obvious, especially when these data are averaged with compositional intervals (Figs. 6c, d). In Fig. 6c, $\mathrm{SiO}_{2}$ and temperatures are averaged in $3.0 \mathrm{wt} \% \mathrm{SiO}_{2}$ intervals, and in Fig. $6 \mathrm{~d}, \mathrm{MgO}$ and temperatures are averaged in $0.5 \mathrm{wt} \% \mathrm{MgO}$ intervals, giving significant trends that can be expressed by

$T_{\mathrm{SiO}_{2}}\left({ }^{\circ} \mathrm{C}\right)=-14.16 \times \mathrm{SiO}_{2}(w t \%)+1723$

$T_{M g O}\left({ }^{\circ} \mathrm{C}\right)=887.6 \times[\mathrm{MgO}(w t \%)]^{0.0989}$
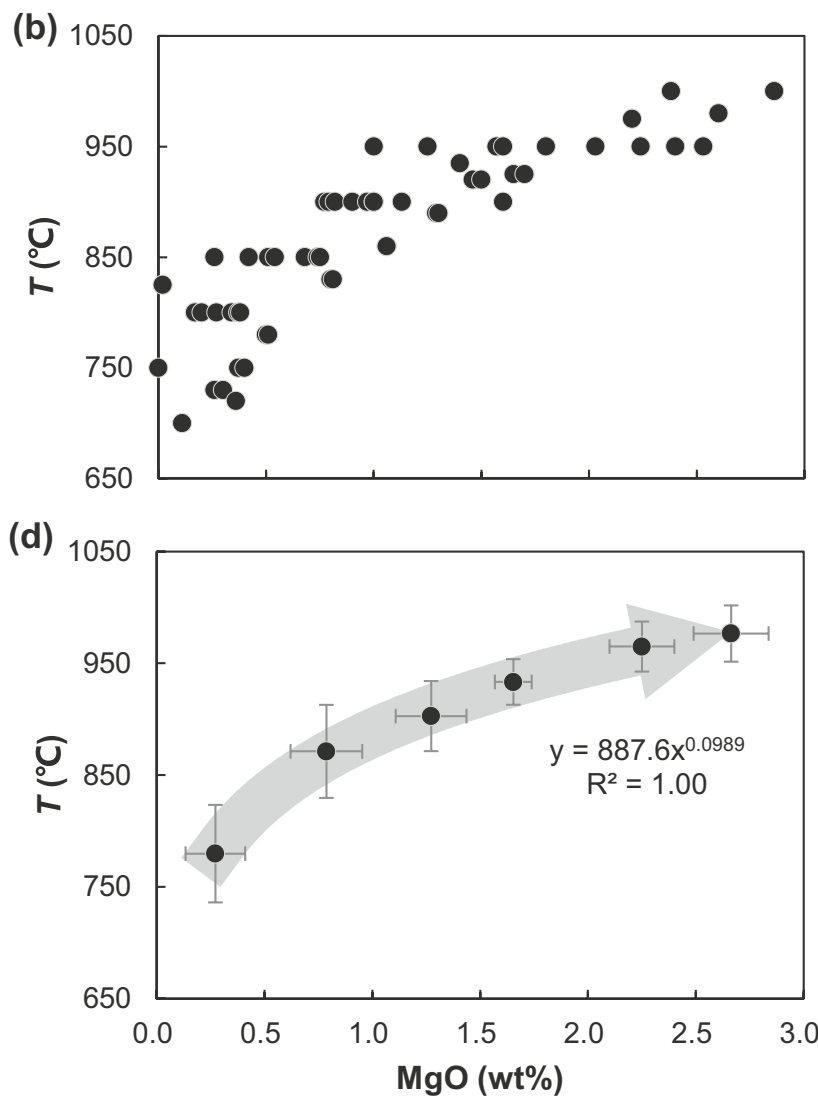

(b) as expected from experimental petrology. The large scatter of the temperature values at a given $\mathrm{SiO}_{2}$ or $\mathrm{MgO}$ results from different experimental conditions. These experimental data are further averaged within the intervals of $3 \mathrm{wt} \% \mathrm{SiO}_{2}$ and $0.5 \mathrm{wt} \% \mathrm{MgO}$ and give simple but reasonable $\mathrm{SiO}_{2}-T(\mathbf{c})$ and $\mathrm{MgO}-T(\mathbf{d})$ relationships 
These two equations are by no means perfect without considering other compositional effects but can effectively capture the predominance of $\mathrm{SiO}_{2}$ and $\mathrm{MgO}$ in describing magma temperatures for felsic and intermediate magmas constrained by experimental phase equilibria.

Figure 7 compares $T_{Z r}$ calculated using Eq. (2) and $T_{\mathrm{SiO}_{2}}$ and $T_{\mathrm{MgO}_{\mathrm{O}}}$ calculated using Eqs. (3) and (4) respectively for the syn-collisional granitoid rocks in central and western China. The good positive trend between $\mathrm{Zr}_{\text {BULK-ROCK }}$ and the calculated $T_{Z r}$ (with correlation coefficient $\mathrm{R}>0.8$ ) simply comes from self-correlation seen in Eq. (2) with the scatter coming from the bulk-rock compositional parameter $M$. It is obvious from Fig. 6 that despite the scatter (Figs. 6a, b) and large uncertainties (Figs. $6 \mathrm{c}, \mathrm{d}$ ), $\mathrm{SiO}_{2}$ and $\mathrm{MgO}$ in the melts can effectively describe the temperatures of granitoid magmatism. Hence, it is logical to use Equs. (3) and (4) to estimate "magma temperatures" for natural granitoid samples. Figure 7 shows these estimates, which, as expected, share no resemblance to $T_{Z r}$ nor show any correlation with $\mathrm{Zr}$ contents. We should note, as discussed above, that no granitoid samples represent true melts (Niu et al. 2013; Lee and Morton 2015), but cumulates from melts or mixtures of melt with crystals (including inherited restite ones) before magma solidification. Hence, the calculated $T_{\mathrm{SiO}_{2}}$ and especially $T_{M g O}$ derived from experimental melts Eqs. (3) and (4) from Fig. 6) in Fig. 7 are not truly magma temperatures, because cumulate minerals (e.g., amphibole) have lower $\mathrm{SiO}_{2}$ and much higher $\mathrm{MgO}$ content than the true melts. This is proven to be the case in Fig. 8, which shows systematically higher $T_{\mathrm{MgO}}$ than $T_{\mathrm{SiO}_{2}}$ in the syn-collisional granitoid rocks in central and western China. However, in contrast to bulkrock $\mathrm{Zr}$ content which varies significantly during magma differentiation and is highly influenced by the crystallized, inherited and captured zircons, the major element composition (especially $\mathrm{SiO}_{2}$ ) of granitoid rocks is sufficiently similar to the composition of the melt. Therefore, Eq. (3) can be used to approximate the magma temperatures.

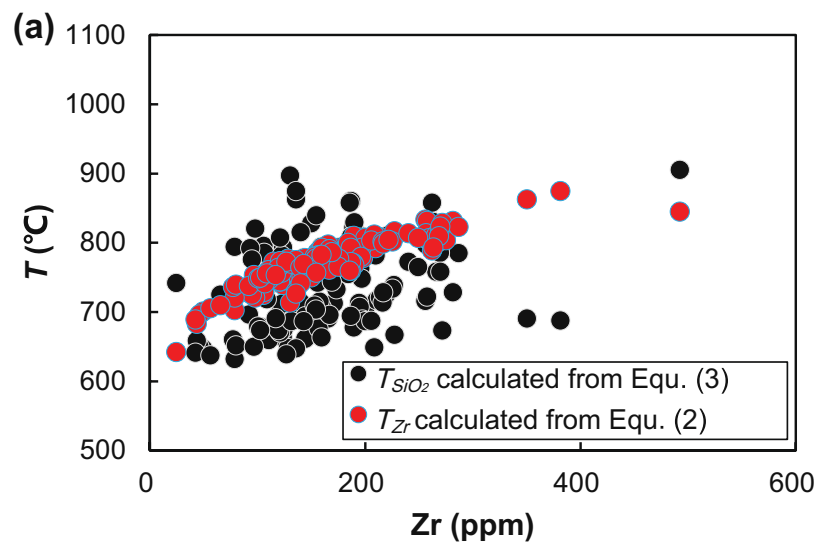

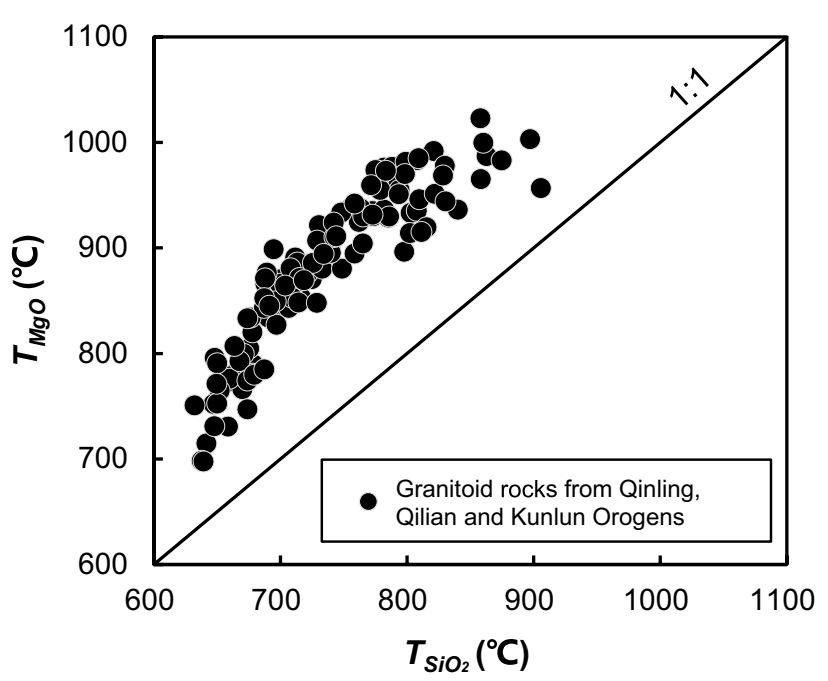

Fig. 8 Comparison between the calculated $T_{\mathrm{MgO}}$ and $T_{\mathrm{SiO}_{2}}$, which shows systematically higher $T_{\mathrm{MgO}}$ than $T_{\mathrm{SiO}_{2}}$

Figure 9 compares $T_{\mathrm{SiO}_{2}}$ calculated using Eq. (3) and $T_{\mathrm{Zr}}$ calculated using Eq. (2) for the natural granitoid samples. Obviously, there is a large discrepancy between the calculated $T_{\mathrm{SiO}_{2}}$ and $T_{\mathrm{Zr}}$, with $T_{\mathrm{SiO}_{2}}$ being generally higher than $T_{Z r}$ for samples with less evolved compositions (e.g., those with $\left.\mathrm{SiO}_{2}<\sim 67 \mathrm{wt} \%\right)$ and and $T_{\mathrm{SiO}_{2}}<T_{\mathrm{Zr}}$ for more evolved samples (e.g., those with $\mathrm{SiO}_{2}>\sim 67 \mathrm{wt} \%$ ) (also see below). In addition, despite the scattering, $T_{\mathrm{SiO}_{2}}$ of granitoid samples have significant correlations with the major element compositions (except for $\mathrm{Na}_{2} \mathrm{O}$ ) as expected in terms of experimental phase equilibria and liquid lines of descent. In contrast, there are no correlations between $T_{Z r}$ and the major element contents. To testify the validity of the above observations, we use downloaded data of worldwide granites from the EarthChem Portal (http://portal.earthchem.org/) on 19 August, 2019, using the following parameters: (1) key words (granites); (2) sample type (plutonic rocks); (3)

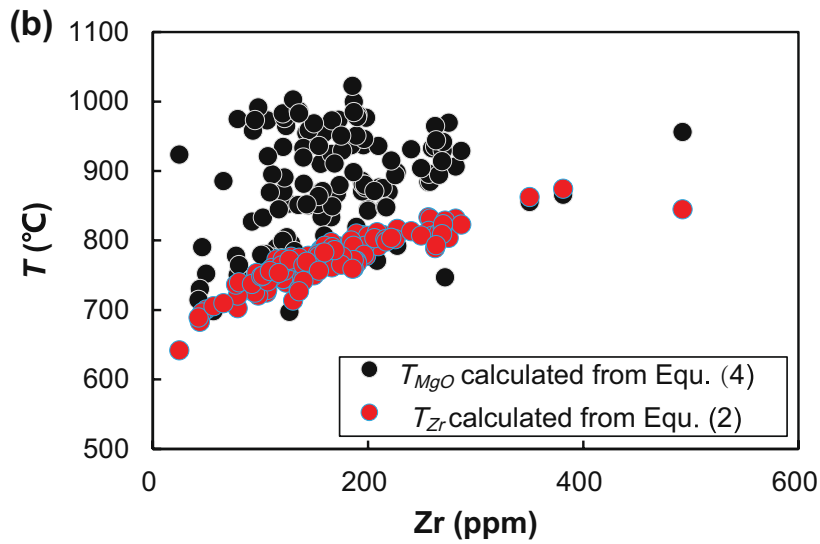

Fig. 7 Plot of the calculated $T_{\mathrm{SiO}_{2}}$ vs. $T_{\mathrm{Zr}}$ (a) and $T_{\mathrm{MgO}}$ vs. $T_{\mathrm{Zr}}(\mathbf{b})$ against whole-rock $\mathrm{Zr}$ contents of granitoid samples 
chemistry (whole-rock major elements and $\mathrm{Zr}$ content). Furthermore, samples with $\mathrm{SiO}_{2}<53 \mathrm{wt} \%, \mathrm{MgO}>6 \mathrm{wt} \%$ and abnormally high $\mathrm{Zr}$ content ( $>1000 \mathrm{ppm}$ ) were left unconsidered. About 400 granite data sets that meet the conditions are used to plot bulk-rock major element compositions as a function of $T_{\mathrm{SiO}_{2}}$ Eq. (3) and $T_{\mathrm{Zr}}$ Eq. (2); Fig. 10. These granite data show similar systematics as the granitoid rocks in central and western China (Fig. 9). The $T_{\mathrm{SiO}_{2}}$ show significant correlations with major element compositions, which are, as expected, consistent with understood liquid lines of decent though these global samples mostly share no genetic relationship. In contrast, the $T_{Z r}$ shows no correlation with major element compositions, indicating its irrelevance to granitoid magma evolution. Hence, it is logical to use bulkrock based $T_{\mathrm{SiO}_{2}}$, instead of $T_{\mathrm{Zr}}$ to estimate the temperature of granitic magmas. Nevertheless, we do not encourage to use individual $T_{\mathrm{SiO}_{2}}$ values as being "exact" but emphasize their petrological significance when comparing between samples and between sample suites in studying the granitoid petrogenesis.

In order to further compare the $T_{\mathrm{SiO}_{2}}$ and $T_{\mathrm{Zr}}$ values calculated from natural granitoid samples and from data sets collected from the EarthChem portal, we use $\Delta T\left(=T_{\mathrm{SiO}_{2}}\right.$ $-T_{\mathrm{Zr}}$ ) to show the deviation between the calculated $T_{\mathrm{SiO}_{2}}$ and $T_{Z r}$ and as a function of $\mathrm{SiO}_{2}$ and bulk-rock $\mathrm{Zr}$ content, respectively (Fig. 11). From Fig. 11a, $\Delta T$ show tight negative correlation with $\mathrm{SiO}_{2}$, ranging from $\sim+400{ }^{\circ} \mathrm{C}$ for intermediate dioritic rocks with low $\mathrm{SiO}_{2}$ to $-300{ }^{\circ} \mathrm{C}$ for felsic granitic rocks with high $\mathrm{SiO}_{2}$. Figure 11a illustrates significant deviation of the calculated $T_{Z r}$ values from the likely magma temperatures approximated by $T_{\mathrm{SiO}_{2}}$ (see above), with the $T_{\mathrm{Zr}}$ values lower than the expected magma temperature $(\Delta T>0)$
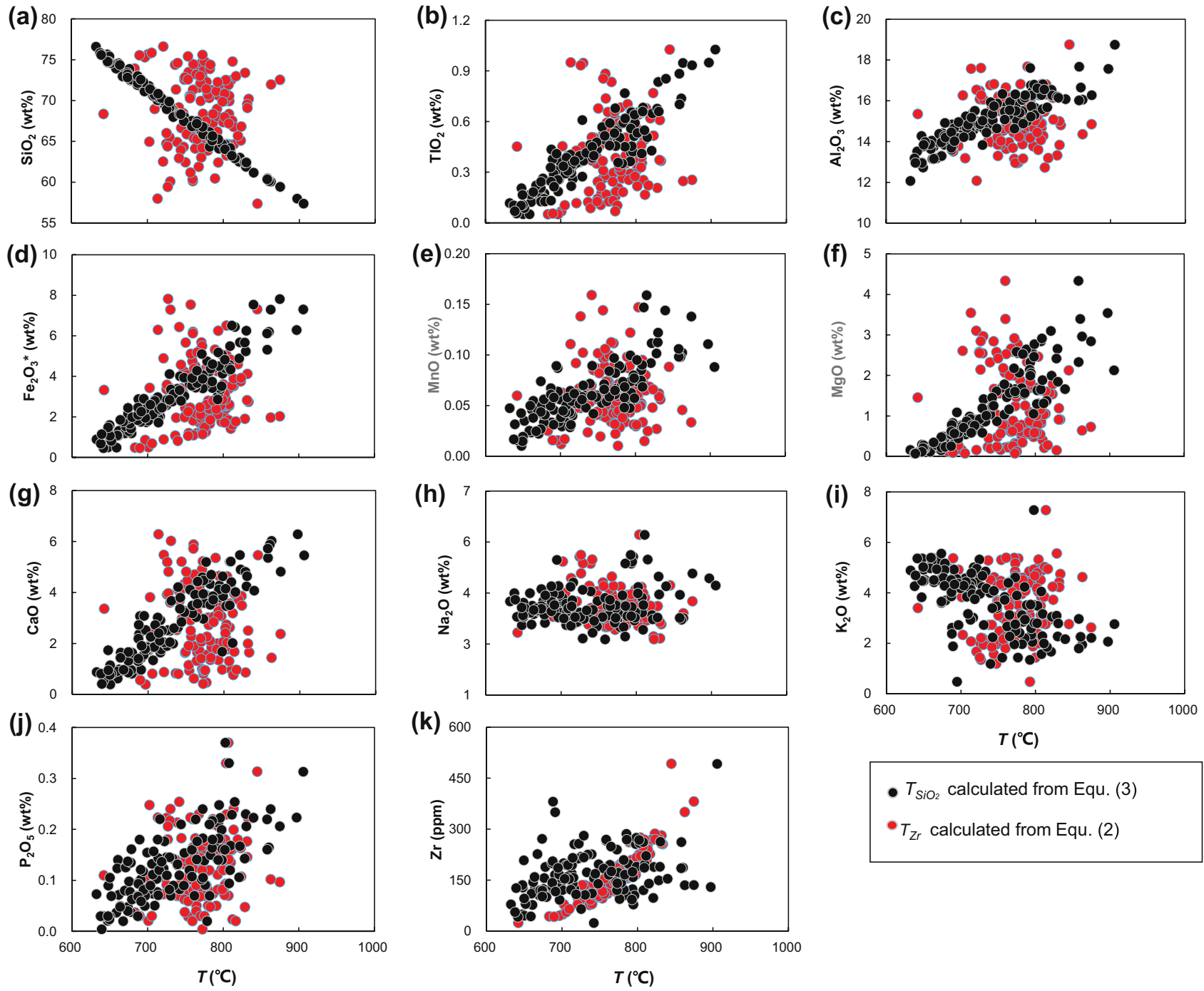

Fig. 9 Correlations of the major elements and whole-rock $\mathrm{Zr}$ contents with calculated $T_{\mathrm{SiO}_{2}}$ vs. $T_{\mathrm{Zr}}$ of the granitoid samples. Total Fe expressed as $\mathrm{Fe}_{2} \mathrm{O}_{3} *$ (wt \%). Same samples and data as in Fig. 2 

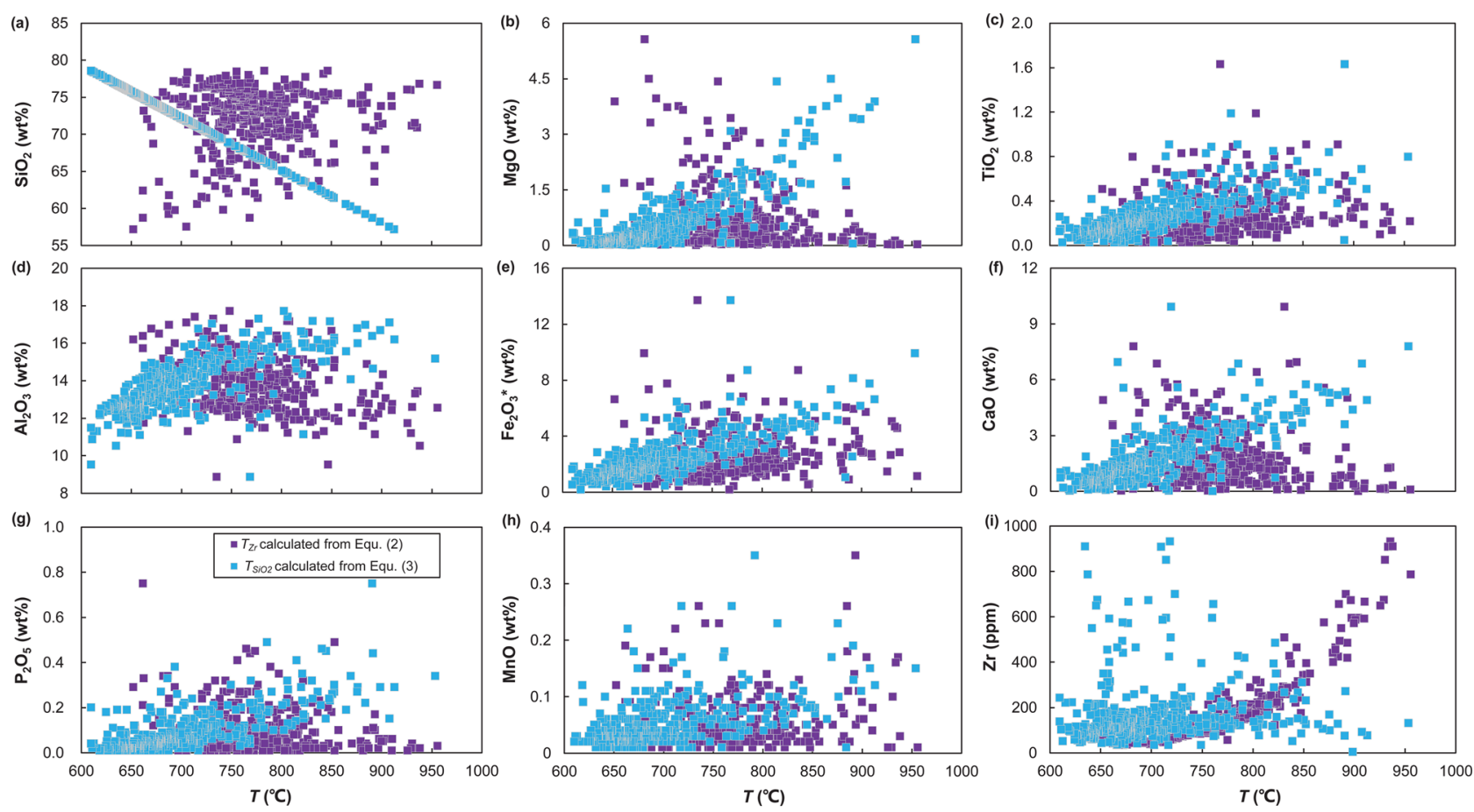

Fig. 10 Plots of the major elements and whole-rock $\mathrm{Zr}$ contents against the calculated $T_{\mathrm{SiO}_{2}}$ vs. $T_{\mathrm{Zr}}$ of granitoid samples compiled from the EarthChem Portal (http://portal.earthchem.org). Total Fe expressed as $\mathrm{Fe}_{2} \mathrm{O}_{3} *$ (wt $\%$ ). The $T_{\mathrm{Zr}}$ values calculated using zircon saturation thermometry (Watson and Harrison 1983) do not show any correlations with major element compositions for intermediate dioritic rocks (low $\mathrm{SiO}_{2}$ ) and higher than the expected magma temperatures $(\Delta T<0)$ for felsic granitic rocks (high $\mathrm{SiO}_{2}$ ). The above observation is in fact consistent with the simulation in Fig. 1. For intermediate dioritic rocks which usually show cumulate texture and represent early fractionation products from the melts, most $\mathrm{Zr}$ resides

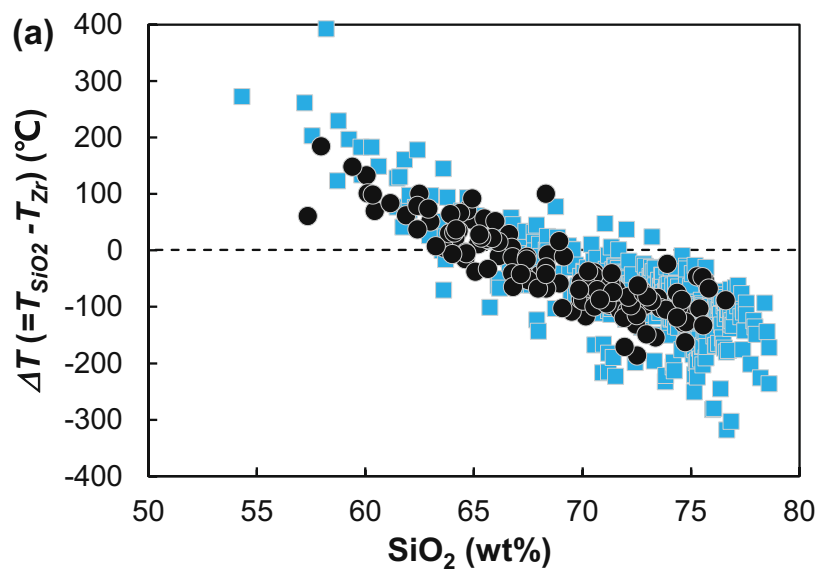

Fig. 11 The differences of calculated temperatures using the two different methods of $\Delta T\left(=T_{\mathrm{SiO}_{2}}-T_{\mathrm{Zr}}\right)$ with $\mathrm{SiO}_{2}$ (a) and bulk rock $\mathrm{Zr}$ content (b). $\Delta T$ shows an apparent negative relationship with $\mathrm{SiO}_{2}$; the intermediate rocks with $<\sim 67 \mathrm{wt} \% \mathrm{SiO}_{2}$ having positive $\Delta T$ and more felsic rocks with $>67 \mathrm{wt} \% \mathrm{SiO}_{2}$ having negative $\Delta T(\mathbf{a})$. There- in the residual melts. In this case, $\mathrm{Zr}_{\text {BULK DIORITIC ROCKS is }}$ much lower than the true $\mathrm{Zr}_{\mathrm{MELT}}$, and $T_{Z r}$ calculated using this low $\mathrm{Zr}_{\text {BULK DIORITIC ROCKS }}$ gives lower values than the actual magma temperatures $(\Delta T>0)$. On the other hand, the more felsic granitic rocks reflecting high viscosity magma are mixtures of melt and crystals with high abundances

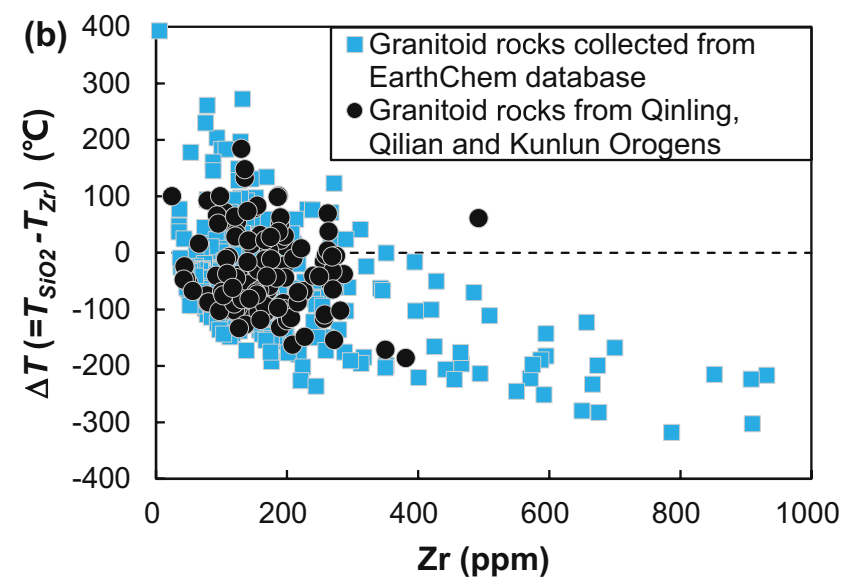

fore, the deviation between the calculated $T_{Z r}$ and the realistic magma temperature approximated by $T_{\mathrm{SiO}_{2}}$ is mainly caused by the deviation between $\mathrm{Zr}_{\text {BULK-ROCK }}$ and the true $\mathrm{Zr}_{\text {MELT }}$ as illustrated by the negative correlation between $\mathrm{Zr}_{\text {BULK-ROCK }}$ and $\Delta T$ (b) 
of zircons of varying origin (liquidus, captured or inherited crystals). Therefore, the $\mathrm{Zr}_{\text {BULK GRANITIC ROCKS }}$ are much higher than $\mathrm{Zr}_{\mathrm{MELT}}$ and the calculated $T_{Z r}$ using high $\mathrm{Zr}_{\text {BULK GRANITIC ROCKS }}$ gives higher values than the true magma temperatures $(\Delta T<0)$. This is further illustrated by the negative correlation between the bulk rock $\mathrm{Zr}$ content and $\Delta T$ (Fig. 11b). Samples with low $\mathrm{Zr}$ content showing positive $\Delta T$ and underestimated $T_{Z r}$ whereas samples with high $\mathrm{Zr}$ content showing negative $\Delta T$ and overestimated $T_{Z r}$ (Fig. 11b).

In fact, the failure in using bulk-rock $\mathrm{Zr}$ content to estimate the magma temperature of granitoids is evident in theory. This is because in contrast with $\mathrm{SiO}_{2}$ that is essential constituents of silicate minerals and rocks, $\mathrm{Zr}$ is petrologically not required for granitoid magmatism. It is important to note that we do not devalue the significance of $\mathrm{Zr}$ because it determines the presence and abundance of zircons in granitic rocks and zircons contain valuable information such as the age of granitoid crystallization and also the ages of granitoid magma sources and source histories preserved in captured and inherited zircons. However, we should also note the fact that $\mathrm{Zr}$ (as a trace/minor element) and zircon (as an accessory mineral) do not participate in and thus cannot control the granitoid phase equilibria. Hence, it is logical and readily understood that $\mathrm{Zr}$ content in a rock cannot provide information on phase equilibria, including the magma temperature. This simple analysis plus the illustrations above explain that there is no thermodynamic and/or petrological reason why the granitoid magma temperatures as approximated by $T_{\mathrm{SiO}_{2}}$ should correlate with bulk-rock $\mathrm{Zr}$ contents (Figs. 9k, 1). Hence, the calculated $T_{Z r}$ values give no information on magma temperatures but are derivatives of $\mathrm{Zr}_{\text {BULK-ROCK }}$. Therefore, we conclude that caution is needed before indiscriminate and continued use of the zircon saturation thermometry.

\section{Conclusions}

Zircon-saturation thermometry has been a convenient tool widely used to calculate magma temperatures in granitoid studies over the last decades. It uses $\mathrm{Zr}_{\mathrm{MELT}}$ as an input because experimental calibration shows $T_{\mathrm{Zr}} \propto \mathrm{Zr}_{\mathrm{MELT}}$. However, what is available in rock samples is $\mathrm{Zr}_{\text {BULK-ROCK }}$, not $\mathrm{Zr}_{\text {MELT }}$. Because for felsic granitic rocks representing mixtures of melts and crystals, $\mathrm{Zr}_{\text {MELT }}$ (unknown) $=\mathrm{Zr}_{\text {BULK-ROCK }}$ - $\mathrm{Zr}_{\text {ZIRCON }}$ (49.7 wt\% Zr with unknown abundance) - $\mathrm{Zr}_{\text {OTHER CUMULATE MINERALS }}$, and for early cumulate dioritic rocks, $\mathrm{Zr}_{\text {BULK-ROCK }}$ is lower than $\mathrm{Zr}_{\mathrm{MELT}}, T_{\mathrm{Zr}}$ values calculated using $\mathrm{Zr}_{\text {BULK-ROCK }}$ thus have no petrological significance.

$\mathrm{Zr}$ as a trace element in rocks and magmas and zircon as an accessory mineral do not participate in and cannot control the granitoid phase equilibria. Therefore, there is no petrological footing that $\mathrm{Zr}_{\text {BULK-ROCK }}$ should correlate with granitoid magma temperatures. We suggest using $\mathrm{SiO}_{2}$ content as a proxy to estimate granitoid magma temperatures, $T_{\mathrm{SiO}_{2}}$, because $\mathrm{SiO}_{2}$ is an essential constituent of granitoid rocks and magmas, and because $\mathrm{SiO}_{2} \propto 1 / T$ is constrained by experimental phase equilibria.

Because granitoids do not represent melt compositions, but the compositions of mixtures of cumulate crystals and inefficiently extracted melt, we do not encourage to accept the calculated $\mathrm{TSO}_{2}$ as true magma temperatures for individual samples, but we advocate the petrological and geological significance of varying $T_{\mathrm{SiO}_{2}}$ values between samples and between sample groups for comparison in the study of granitoid petrogenesis.

Acknowledgements We thank two anonymous reviewers, and editors Qiang Wang and Lutz Nasdala, whose constructive comments helped to improve significantly the manuscript. This study is supported by the National Natural Science Foundation of China (NSFC; grants 41130314,91014003 ), Chinese Academy of Sciences (Innovation grant Y422171011L) and 111 Project (B18048).

Open Access This article is licensed under a Creative Commons Attribution 4.0 International License, which permits use, sharing, adaptation, distribution and reproduction in any medium or format, as long as you give appropriate credit to the original author(s) and the source, provide a link to the Creative Commons licence, and indicate if changes were made. The images or other third party material in this article are included in the article's Creative Commons licence, unless indicated otherwise in a credit line to the material. If material is not included in the article's Creative Commons licence and your intended use is not permitted by statutory regulation or exceeds the permitted use, you will need to obtain permission directly from the copyright holder. To view a copy of this licence, visit http://creativecommons.org/licenses/by/4.0/.

\section{References}

Alonso-Perez R, Müntener O, Ulmer P (2008) Igneous garnet and amphibole fractionation in the roots of island arcs: experimental constraints on andesitic liquids. Contrib Mineral Petr 157:541-558

Anderson JL, Barth AP, Wooden JL, Mazdab F (2008) Thermometers and thermobarometers in granitic systems. In: Putirka KD, Tepley III FJ (eds) Minerals, Inclusion and Volcanic Processes. Rev Mineral Geochem. Mineral Soc Am Chantilly 69:121-142

Barnes CG, Werts K, Memeti V, Ardill K (2019) Most Granitoid Rocks are Cumulates: Deductions from Hornblende Compositions and Zircon Saturation. J Petrol 60:2227-2240

Bender JF, Hodges FN, Bence AE (1978) Petrogenesis of basalts from the project FAMOUS area: experimental study from 0 to $15 \mathrm{kars}$. Earth Planet Sc Lett 41:277-302

Benisek A, Dachs E, Kroll H (2010) A ternary feldspar-mixing model based on calorimetric data: development and application. Contrib Mineral Petr 160:327-337

Benisek A, Kroll H, Cemič L (2004) New developments in two-feldspar thermometry. Am Mineral 89:1496-1504

Boehnke P, Watson EB, Trail D, Harrison TM, Schmitt AK (2013) Zircon saturation re-revisited. Chem Geol 351:324-334

Bowen NL (1928) The Evolution of the Igneous Rocks. Princeton University Press 
Brown WL, Parsons I (1981) Towards a more practical two-feldspar geothermometer. Contrib Mineral Petr 76:369-377

Carroll MR, Wyllie PJ (1989) Experimental Phase Relations in the System Tonalite-Peridotite-H2O at $15 \mathrm{~kb}$; Implications for Assimilation and Differentiation Processes near the Crust-Mantle Boundary. J Petrol 30:1351-1382

Chen S, Niu YL, Li JY, Sun WL, Zhang Y, Hu Y, Shao FL (2016) Syncollisional adakitic granodiorites formed by fractional crystallization: Insights from their enclosed mafic magmatic enclaves (MMEs) in the Qumushan pluton, North Qilian Orogen at northern margin of the Tibetan Plateau. Lithos 248-251:456-468

Chen S, Niu YL, Sun WL, Zhang Y, Li JY, Guo PY, Sun P (2015) On the origin of mafic magmatic enclaves (MMEs) in syn-collisional granitoids: evidence from the Baojishan pluton in the North Qilian Orogen, China. Miner Petrol 109:577-596

Clemens JD, Stevens G (2012) What controls chemical variation in granitic magmas? Lithos 134-135:317-329

Duan M, Niu YL, Kong JJ, Sun P, Hu Y, Zhang Y, Chen S, Li JY (2016) Zircon U-Pb geochronology, Sr-Nd-Hf isotopic compositions and geological significance off the Late Triassic Baijiazhuang and Lvjing granitic plutons in West Qinling Orogen. Lithos 260:443-456

Gerke TL, Kilinc AI (1993) Enrichment of $\mathrm{SiO}_{2}$ in rhyolites by fractional crystallization: an experimental study of peraluminous granitic rocks from the St. Francois Mountains, Missouri, USA. Lithos 29:273-283

Grove TL, Donnelly-Nolan JM, Housh T (1997) Magmatic processes that generated the rhyolite of Glass Mountain, Medicine Lake volcano. N California Contrib Mineral Petr 127:205-223

Grove TL, Kinzler RJ, Bryan WB (1992) Fractionation of mid-ocean ridge basalt (MORB). In: Morgan JP, Blackman DK, Sinton JM (eds) Mantle flow and melt generation at mid-ocean ridges. AGU American Geophysical Union. Washington, DC 71:281-310

Hanchar JM, Watson EB (2003) Zircon Saturation Thermometry. In: Hanchar JM, Hoskin PWO (eds) Zircons. Rev Mineral Geochem. Mineral Soc Am Chantilly 53:89-112

Helz RT (1976) Phase relations of basalts in their melting ranges at $P$ $\mathrm{H}_{2} \mathrm{O}=5 \mathrm{~kb}$. Part II Melt Compositions J Petrol 17:139-193

Kong JJ, Niu YL, Hu Y, Zhang Y, Shao FL (2020) Petrogenesis of the Triassic granitoids from the East Kunlun Orogenic Belt, NW China: Implications for continental crust growth from syncollisional to post-collisional setting. Lithos 364/365:105513

Kong JJ, Niu YL, Duan M, Xiao YY, Zhang Y, Guo PY, Sun P, Gong HM (2019) The syncollisional granitoid magmatism and crust growth during the West Qinling Orogeny, China: Insights from the Jiaochangba pluton. Geol J 54:4014-4033

Kong JJ, Niu YL, Duan M, Zhang Y, Hu Y, Li JY, Chen S (2017) Petrogenesis of Luchuba and Wuchaba granitoids in western Qinling: geochronological and geochemical evidence. Miner Petrol 111:887-908

Kroll H, Evangelakakis C, Voll G (1993) Two-feldspar geothermometry: a review and revision for slowly cooled rocks. Contrib Mineral Petr 114:510-518

Langmuir CH, Hanson GN (1981) Calculating mineral-melt equilibria with stoichiometry, mass balance, and single component distribution coefficients. In: Newton RC, Navrotsky A, Wood BJ (eds) Thermodynamics of Minerals and Melts. Springer-Verlag New York 1981. Springer, New York 1:247-271

Lee CTA, Morton DM (2015) High silica granites: Terminal porosity and crystal settling in shallow magma chambers. Earth Planet Sc Lett 409:23-31

Li JY, Niu YL, Chen S, Sun WL, Zhang Y, Liu Y, Ma YX, Hu ZX, Zhang GR (2017) Petrogenesis of granitoids in eastern section of the Central Qilian Block: Evidence from geochemistry and zircon U-Pb geochronology. Miner Petrol 111:23-41

Li JY, Niu YL, Hu Y, Chen S, Zhang Y, Duan M, Sun P (2016) Origin of the late Early Cretaceous granodiorite and associated dioritic dikes in the Hongqilafu pluton, northwestern Tibetan Plateau: A case for crust-mantle interaction. Lithos 260:300-314

Miller CF, McDowell SM, Mapes RW (2003) Hot and cold granites? Implications of zircon saturation temperature and preservation of inheritance. Geology 31:529-532

Moore G, Carmichael ISE (1998) The hydrous phase equilibria (to 3 kbar) of an andesite and basaltic andesite from western Mexico: constraints on water content and conditions of phenocryst growth. Contrib Mineral Petr 130:304-319

Nandedkar RH, Ulmer P, Müntener O (2014) Fractional crystallization of primitive, hydrous arc magmas: an experimental study at $0.7 \mathrm{GPa}$. Contrib Mineral Petr 167:1015

Nandedkar RH, Hürlimann N, Ulmer P, Müntener O (2016) Amphibolemelt trace element partitioning of fractionating calc-alkaline magmas in the lower crust: an experimental study. Contrib Mineral Petr 171:71

Nielsen RL, Dungan MA (1983) Low pressure mineral-melt equilibria in natural anhydrous mafic systems. Contrib Mineral Petr 84:310-326

Niu YL, Gilmore T, Mackie S, Greig A, Bach W (2002) Mineral chemistry, whole-rock compositions, and petrogenesis of Leg 176 gabbros: data and discussion. Proc. ODP. Sci Results 176:1-60

Niu YL, Zhao Z, Zhu DC, Mo XX (2013) Continental collision zones are primary sites for net continental crust growth - A testable hypothesis. Earth-Sci Rev 127:96-110

Roeder PL, Emslie RF (1970) Olivine-Liquid Equilibrium Contrib Mineral Petr 29:275-289

Shao FL, Niu YL, Liu Y, Chen S, Kong JJ, Duan M (2017) Petrogenesis of Triassic granitoids in the East Kunlun Orogenic Belt, northern Tibetain Plateau and their tetonic implications. Lithos 282-283:33-44

Sisson T, Grove T (1993) Experimental investigations of the role of $\mathrm{H}_{2} \mathrm{O}$ in calc-alkaline differentiation and subduction zone magmatism. Contrib Mineral Petr 113:143-166

Tuttle OF, Bowen NL (1958) Origin of granite in the light of experimental studies in the system $\mathrm{NaAlSi}_{3} \mathrm{O}_{8}-\mathrm{KAlSi}_{3} \mathrm{O}_{8}-\mathrm{SiO}_{2}-\mathrm{H}_{2} \mathrm{O}$. Geol Soc Am 74:153

Ulmer P, Kaegi R, Müntener O (2018) Experimentally Derived Intermediate to Silica-rich Arc Magmas by Fractional and Equilibrium Crystallization at 1.0 GPa: an Evaluation of Phase Relationships, Compositions, Liquid Lines of Descent and Oxygen Fugacity. J Petrol 59:11-58

Walker D, Shibata T, Delong SE (1979) Abyssal tholeiites from the Oceanographer fracture zone. Contrib Mineral Petr 70:111-125

Watson EB (1979) Zircon saturation in felsic liquids: experimental results and applications to trace element geochemistry. Contrib Mineral Petr 70:407-419

Watson EB, Harrison TM (1983) Zircon saturation revisited: temperature and compositions effects in a varity of crustal magma types. Earth Planet Sc Lett 64:295-304

Watson EB, Harrison TM (1984) Accessory minerals and the geochemical evolution of crustal magmatic systems: a summary and prospectus of experimental approaches. Phys Earth Planet in 35:19-30

Weaver JS, Langmuir CH (1990) Calculation of phase equilibrium in mineral-melt systems. Comput Geosci-UK 16:1-19

Zhang Y, Niu YL, Hu Y, Liu JJ, Ye L, Kong JJ, Duan M (2015) The syncollisional granitoid magmatism and continental crust growth in the West Kunlun Orogen, China - Evidence from geochronology and geochemistry of the Arkarz pluton. Lithos 245:191-204

Publisher's Note Springer Nature remains neutral with regard to jurisdictional claims in published maps and institutional affiliations. 